\title{
Introductory studies of bacterial effects on the course of mitosis in adventitious roots of Allium cepa L.
}

\author{
J. CEBRAT, K. CZERWIŃSKA, K. BOHDANOWICZ-MUREK \\ Department of Plant Anatomy and Cytology and Department of Microbiology \\ University of Wroclaw, ul. Kanonia $6 / 8$ \\ (Received: June 21, 1971)
}

\section{Abstract}

The level of spontaneous chromosome aberrations and other phenomena concomitant with mitoses in the meristematic cells of Allium cepa L. adventitious roots grown in water, depends to a large extent on the intensity of bacteria multiplication. From the water culture two strains of bacteria, which were most numerous, were isolated - Agrobacterium and Flavobacterium. A supernatant from bacteria grown on Davis medium induced chromosome sticking together, c-mitoses and the formation of polyploid nuclei in the roots of onion.

\section{INTRODUCTION}

During initial observations it was found that advantitious roots of onions - Allium cepa L., cultured in tap water at a temperature of $22 \mathrm{C}$ differ in:

1. the percentage of anaphases with bridges and chromosome fragments (Plate I, Photo 9 and 10); among the 200 onions studied the percentage of anaphases with chromosome aberrations fluctuated between about 0 to $48 \%$. In each of the onions $100-500$ anaphases were studied.

2. the stickiness of the chromosomes; in some of the experimental series bridges dominated among the anaphases with chromosomal aberrations, while in other anaphases chromosomal fragments were more common (Table 1).

3. the length of chromosomes (Photo 3 and 7).

4. the degree of synchronization of chromosome movements in anaphase (Photo 4 and 8).

5 . the occurrence or absence of dividing polyploid cells (Photo 6). The purpose of experiments reported here was to investigate whether 
Table 1

Frequency of bridges and of chromosome fragments in the total number of anaphases with spontaneous chromosomal aberrations in the advetitious roots of onion, cultured on tap water in the experimental series conducted during the years 1968 and 1970

\begin{tabular}{|c|c|c|c|c|c|}
\hline $\begin{array}{c}\text { Date } \\
\text { of } \\
\text { experiment }\end{array}$ & $\begin{array}{c}\text { No. of studied } \\
\text { anaphases } \\
\text { with } \\
\text { aberrations }\end{array}$ & bridges & fragments & $\begin{array}{c}\text { Poth bridges } \\
\text { and } \\
\text { fragments }\end{array}$ & $\begin{array}{c}\text { No. of studied } \\
\text { onions }\end{array}$ \\
\cline { 3 - 6 } 1968 & 105 & 70 & 23 & 7 & 49 \\
1970 & 296 & 16 & 76 & 8 & 137 \\
\hline
\end{tabular}

the observed differences are genetic or are caused by variable environmental factors.

It was noted that the water in which the onions were cultured frequently becomes turbid as a result of the multiplication of bacteria. It is suggested that the substances exuded by the bacteria into the water are responsible for the phenomena described above. Such possibility was also suggested by Wipf and Cooper (1940), who have shown that there exists a relation between the infection with Rhizobium and the occurrence of polyploid cells in the nodules of leguminose plants, and by Jakowska (1949) and D'A mato (1950) who reported that the polyploidization of some onion root cells results from infection with Bacterium tumefaciens. Therefore in one of the experiments the onions were divided into two groups on the basis of the degree of turbidity of the water in which they have been grown, which depends on the number of bacteria in it, and the level of chromosomal aberrations in these two groups was investigated. The number of aberrations proved to be distinctly dependent on the abundance of bacteria in the water (Table 2).

These results stimulated us to attempt to isolate from the

Table 2

Level of chromosomal aberrations in the adventitious roots of onions depending on the degree of bacterial multiplication in the water

\begin{tabular}{|l|c|c|c|}
\hline & $\begin{array}{c}\text { Percentage } \\
\text { with } \\
\text { aberrations }\end{array}$ & $\begin{array}{c}\text { No. of studied } \\
\text { anaphases }\end{array}$ & $\begin{array}{c}\text { No. of studied } \\
\text { onions }\end{array}$ \\
\hline Water with small bacterial content & 0,8 & 1200 & 12 \\
Water with large bacterial content & 4,8 & 2500 & 25 \\
\hline
\end{tabular}


turbid water in which the onions were cultured the bacterial strains which might have been responsible for changes in the course of mitosis.

\section{MATERIALS AND METHODS}

Isolation and identification of the bacterial strains

The bacteria were isolated from the turbid water of nonsterile cultures of onions in the roots of which a high level of chromosomal aberrations were observed. The number of bacteria in water were determined by plating appriopriate dilutions on nutrient agar. On the plates two types of colonies were observed: white, designated as $313 \mathrm{a}$, occurring in a number of $1,7 \times 10^{7}$ cells per $\mathrm{ml}$ of water, and yellow ones, designated as $313 \mathrm{~b}$ occurring in a number $4,1 \times 10^{5}$ cells per ml of water. After purification these two strains were used for the further studies. In order to identify the isolated strains several morphological, anatomical and biochemical tests were conducted. Results of these are presented in Table 3 .

During identification it became obvious that the isolated strains of bacteria develop well on a synthetic medium according to $\mathrm{D}$ avis (L e d e r berg 1950) consisting of: $\mathrm{K}_{2} \mathrm{HPO}_{4}-7 \mathrm{~g}, \mathrm{KH}_{2} \mathrm{PO}_{4}-2 \mathrm{~g}$, sodium citrate $-0,5 \mathrm{~g}, \mathrm{MgSO}_{4} \cdot 7 \mathrm{H}_{2} \mathrm{O}-0,1 \mathrm{~g},\left(\mathrm{NH}_{4}\right)_{2} \mathrm{SO}_{4}-1 \mathrm{~g}$, glucose $-10 \mathrm{~g}$, distilled water $-1000 \mathrm{ml}$. Since this medium has a strictly defined composition it has been used for the further experiments.

\section{Experimental methods for the study of bacterial effects on the course of mitoses in onion}

Onions, with the external scales peeled off, were sterilized with $0,1 \% \mathrm{HgCl}_{2}$ for $15 \mathrm{~min}$. After sterilization they had been washed in running tap water for about 4 hours, and then they were planted into glass containers with tap water. After $4-5$ days of culture, when the roots reached $3-6 \mathrm{~cm}$ in length, the onions were transferred to a supernatant from the $313 \mathrm{a}$ bacteria and separately to a supernatanit from $313 \mathrm{~b}$, obtained by centrifugation of the cultures at $3000 \mathrm{r} / \mathrm{min}$. Two experiments were conducted. In the first one the course of mitosis in the adventitious roots of onion were studied as affected by the action of the supernatant, obtained following the incubation of bacteria for various lengths of time: 2, 4, 8, 24, 48 and 96 hours; in the second experiment the same observations were made following treatment with a diluted supernatant obtained after 48 and 96 hour incubations. The supernatant was diluted with sterile distilled water 1:8, 1:4, 1:2 and 1:0. Each experiment was repeated three times. Roots were fixed in acetic 
acid with ethyl alcohol (the ratio 1:4). From each onion a part of the roots was fixed directly, before transfer to a supernatant, and some of the roots after 2, 4, 8 and 24 hours of action of the supernatant. The preparations were stained by the nigrosin method.

\section{Table 3}

Characteristic features of the bacterial strains

\begin{tabular}{|c|c|c|}
\hline & strain 313a & strain $313 \mathrm{~b}$ \\
\hline \multicolumn{3}{|l|}{ Cellular characteristics } \\
\hline $\begin{array}{l}\text { Gram strain } \\
\text { Shape } \\
\text { Size } \\
\text { Flagella } \\
\text { Motility }\end{array}$ & $\begin{array}{l}\text { gram negative } \\
\text { rods (Photo 29) } \\
1 \times 0,7 \mu \mathrm{m} \\
\text { present, untypical, distributed } \\
\text { very weak }\end{array}$ & $\begin{array}{l}\text { gram negative } \\
\text { rods }(\text { Photo } 28 \text { ) } \\
3 \times 0,8 \mu \mathrm{m} \\
\text { present, untypical, distributed } \\
\text { present }\end{array}$ \\
\hline \multicolumn{3}{|l|}{ Cultural characteristics } \\
\hline $\begin{array}{l}\text { Nutrient broth } \\
\text { Streak on nutrient agar } \\
\text { Colonies on nutrient agar } \\
\text { Colonies on Davis medium }\end{array}$ & $\begin{array}{l}\text { turbid, membranous ring, } \\
\text { greyish-brown sediment } \\
\text { light cream, glistening } \\
5-8 \mathrm{~mm} \varnothing \text {, light cream } \\
\text { white, convex, slimy (Photo } \\
27)\end{array}$ & $\begin{array}{l}\text { turbid, membranous ring, } \\
\text { greyish-brown sediment } \\
\text { yellow, glistening } \\
5-8 \mathrm{~mm} \varnothing, \text { light cream } \\
\text { light cream, raised, with much } \\
\text { slime (Photo 26) }\end{array}$ \\
\hline \multicolumn{3}{|l|}{ Physiological characteristics } \\
\hline Resistance to $200 \mu \mathrm{g} / \mathrm{ml}$ strep- & & \\
\hline tomycin & $\mathrm{S}$ & $\mathrm{S}$ \\
\hline Gelatine liquefaction & - & + \\
\hline Starch hydrolysis & - & - \\
\hline Urea hydrolysis & - & - \\
\hline Citrate utilization & + & + \\
\hline Nitrate reduction & + & + \\
\hline Cellulose decomposition & - & - \\
\hline Growth on potato & $\begin{array}{l}\text { very poor peptonization, poor } \\
\text { acidification with coagulation } \\
\text { of casein } \\
\text { grayish-brown, glistening, the } \\
\text { potato darkens }\end{array}$ & $\begin{array}{l}\text { very poor peptonization, poor } \\
\text { acidification with coagulation } \\
\text { of casein } \\
\text { yellowish-brown, glistening }\end{array}$ \\
\hline Methyl red reaction & + & - \\
\hline $\begin{array}{l}\text { Acetylmethyl carbinol produc- } \\
\text { tion }\end{array}$ & - & + \\
\hline Hydrogen sulfide production & - & + \\
\hline $\begin{array}{l}\text { Indole production } \\
\text { Fermentation of sugars: } \\
\text { glucose, lactose, xylose, ara- } \\
\text { binose, maltose, galactose, sac- } \\
\text { charose, ramnose, mannitol }\end{array}$ & acid and gas & acid and gas \\
\hline $\begin{array}{l}\text { Most related } \\
\text { (not identical) }\end{array}$ & Agrobacterium radiobacter & Flavobacterium sp. \\
\hline
\end{tabular}




\section{RESULTS}

In the course of experiments it was established that the effects of supernatant from the $313 \mathrm{a}$ and $313 \mathrm{~b}$ strains of bacteria on the adventitious roots of onion was similar. The results are illustrated by photographs 12-25 (Plate I). Photos 16-25 show mitoses in the roots subjected for 4 hours to the treatment with a supernantant of bacterium $313 \mathrm{~b}$ and photos $12-15$ are the controls mitoses from roots cultured for 4 hours in a Davis medium. From a comparision of the mitotic figures from roots cultured in a Davis medium (Photos 12-15) wiln those from water cultures (Photos 1-5) it can be seen that the course of mitosis was not affected by culturing of roots in the medium.

The mode of action of the supernatant on mitosis in adventitious roots of onion depended on the time of bacterial incubation in the medium and on the degree of dilution of the supernatant. After two and four hours incubation of the bacteria no visible effect of the supernatant on mitoses in the roots was observed. A distinct action of the supernatant became evident after an 8-hour incubation of the bacteria. In the roots of onion after a 2 hour treatment with the supernatant, chromosomes in all the dividing cells were distinctly shortened. In some of the cells, which were in the stage of late prophase or in metaphase the sticking together of chromosomes was observed. The mode of adherence was such that the chromosomes formed a three dimentional network (Photo 16). After a 4 hour action of the supernatant distinct accumulation of the methaphases was noted in the majority of cases with the chromosomes stuck together in the form of network. Anaphases and telophases occurred rarely and were characterized by improper and incomplete migration of the chromosomes to the poles. These irregularities were undoubtedly caused by the stickiness of the chromosomes in the earlier phases. From the shape of the anaphase and telophase figures (Photos 17 and 18) one can conclude that the anaphase movements of the chromosomes were kept, but that as a result of the chromosomes being stuck together their full separation into two groups became impossible. This was also undoubtedly the cause of the occurrence of frond-like, polyploid restitution nuclei (Photo 19). After 8 and 24 hours of action of the supernatant the roots remained alive, but the number of mitoses in them was distinctly declined. The mitoses were aberrant in way similar to that described above.

The supernatant of the bacteria incubated for 24, 48 and 96 hours resulted in the death of roots within 8 hours. The observed mitotic figures after 2 and 4 hours of action indicate that the course of mitosis was abruptly inhibited after the transfer of the roots to the supernatant. This indicates that the number of mitoses and of figures in the various phases does not change with time, while simultaneously the process of 


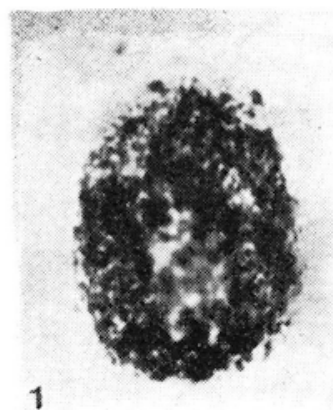

6
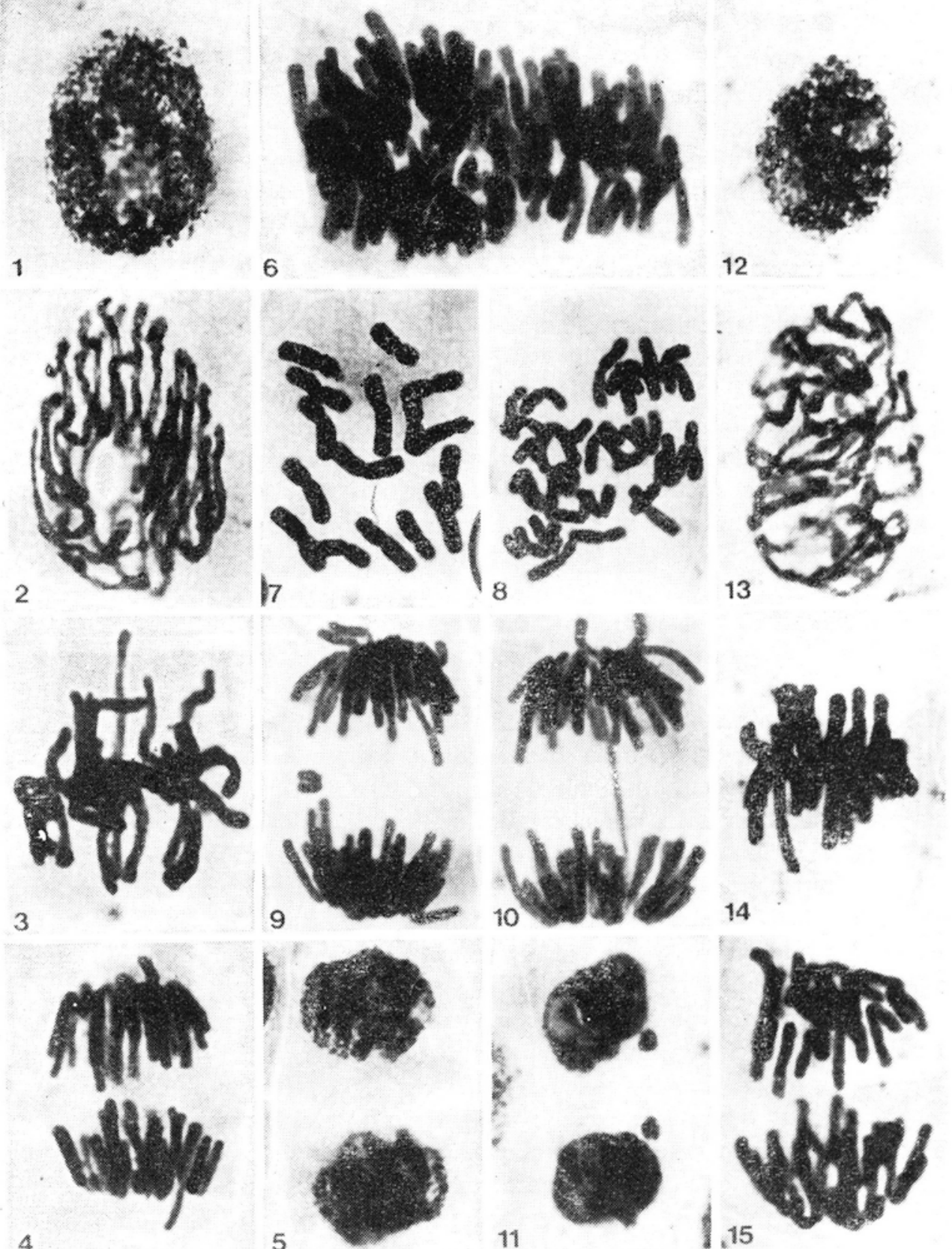

Course of mitosis in the adventitious roots of Allium cepa L.

Photos $1-15$ in control conditions (1-11 in onions cultured all the time on tap water; 12-15 in onions cultured on tap water and then transferred for 4 hours to a Davis medium). Photos 16-25 in onions cultured on tap water and later for 4 hours on a supernatant from a bacterial culture $313 \mathrm{~b}$ following incubation on a Davis medium (16-19 after action of the supernatant from bacteria incubated on the medium for 8 hours; $20-25$ after action of the supernatant from bacteria incubated on the medium for 48 hours. $20-22$ the onions were treated with a non diluted supernatant; $23-25$ the supernatant was diluted $1: 2$ with distilled water). 


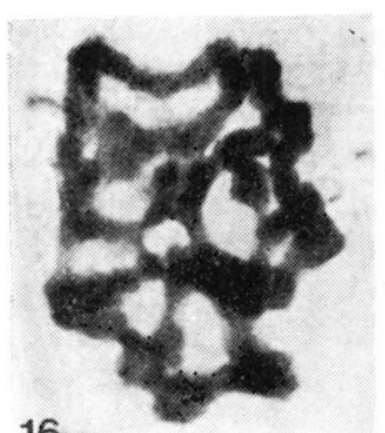

16

17

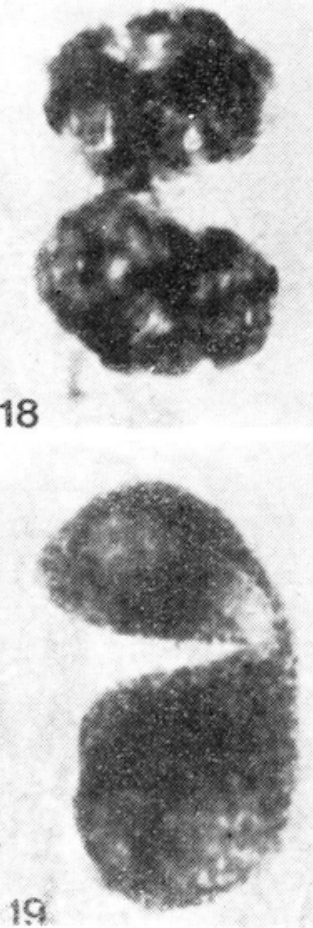

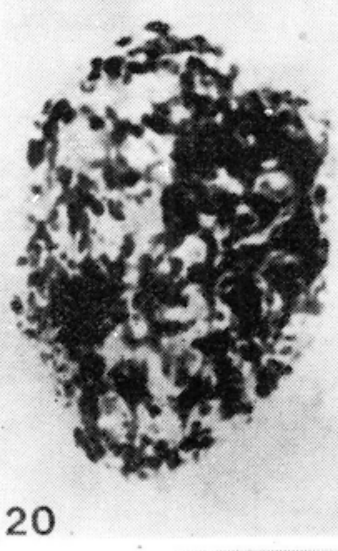

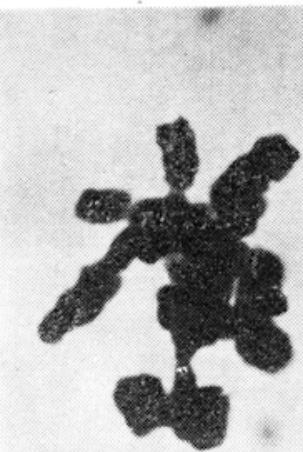

21
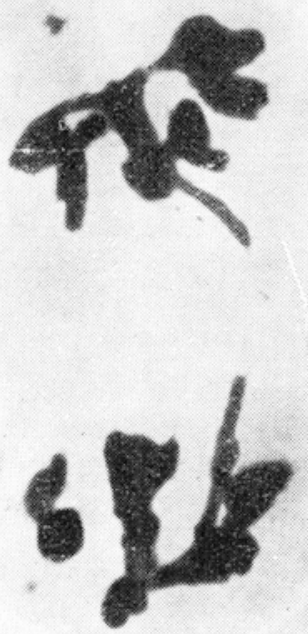

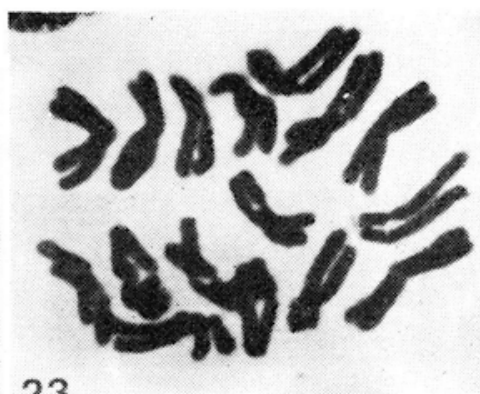

23

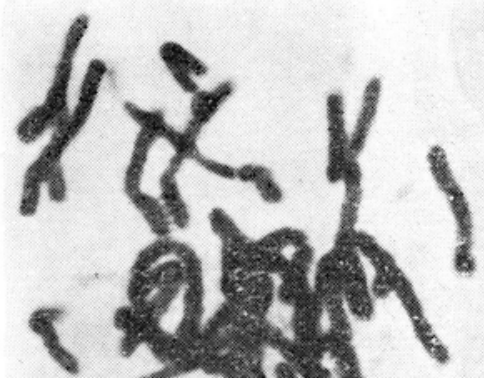

24
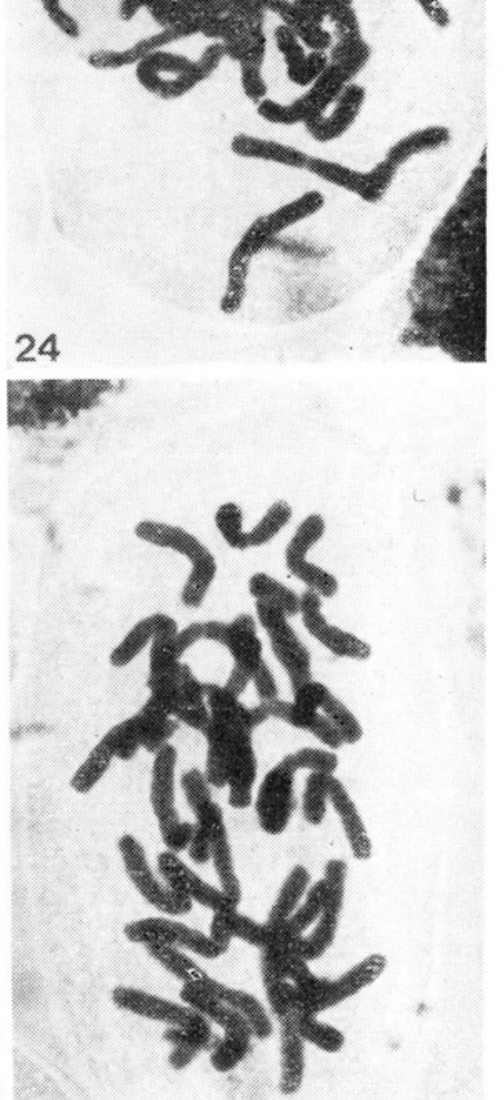

25 
Plate III
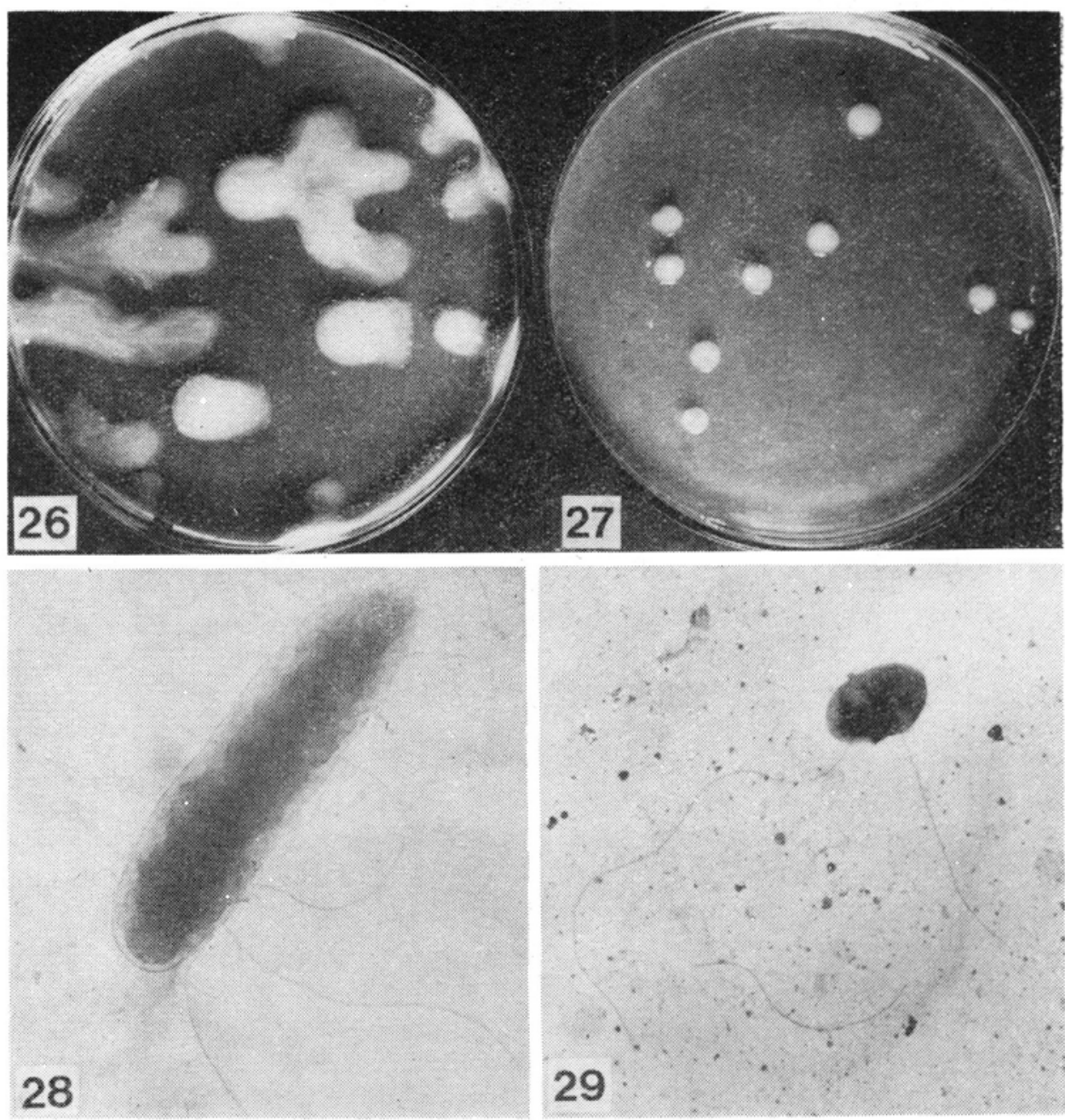

Morphology of the colony and of the cells of the bacteria. Photos 26-27 bacterial colonies on an agar Davis medium (26 - bacterial strain $313 \mathrm{~b} ; 27$ - bacterial strain 313a). Photos 28-29 cells of the bacteria as seen by electron microscopy (28 bacterial strain $313 \mathrm{~b} ; 29$ - bacterial strain $313 \mathrm{a}$ ). 
deformation of the mitotic figures and changes in the structure of the interphase nuclei advances rapidly. After a 4 hour action chromosomes of cells in the metaphase stage undergo a strong contraction and become stuck together in various shapes (Photo 21). In anaphases the typical bipolar arrangement of chromosomes is kept. However the chromosomes lose their individual shapes and stick together in groups forming irregular shapes (Photo 22). In many interphase nuclei a condensation of chromatin into numerous droplets results (Photo 20). These changes were undoubtedly associated with the dying of the cells.

A dilution of the supernatant from bacterial cultures incubated for 48 and 96 hours, using distilled water in the ratio 1:2 prevented the dying of the rosts. In roots subjected to the action of a diluted supernatant such phenomena were observable which indicated that the mitotic spindle became inactivated. These phenomena were the accumulation of metaphases, the appearance of c-metaphases (Photo 23) and c-anaphases (Photo 24 ) and the formation of the polyploid restitution nuclei. In the same roots mitoses were also observed which were similar to normal ones and whole series of mitotic figures which were intermediate in character (Photo 25). A further dilution of the supernatant (1:3 and 1:7) resulted in a complete disappearance of the deforming action on mitosis.

\section{DISCUSSION}

The studies of the last few years have shown that pathogenic microorganisms have to be taken into consideration as potential agents of spontaneous chromosomal aberrations. It was found that numerous viruses cause in animals and in man the fragmentation of chromesomes (H a m par and Ellis on 1961; Nichols 1963; Nichols, Levan, A u la and Norrby 1964, 1965; Z ats epin et al. 1970), aberrations in cell division leading to the formation of polynucleate cells ( $\mathrm{H}$ e $\mathrm{n}$ e e $\mathrm{n}$, $\mathrm{Nichols}$, Levan and Norrby 1970), and the lowering of the mitotic activity (V a s kova and L'vov 1970). In the meiosis of larvae of some insects, it was found that rickettsiae are responsible for the breaking of chromosomes and for the formation of chromosomal bridges ( $\mathrm{Halk \textrm {ka }}$, M a y adi er, Vago and Brummer-Kornvenkotio 1970). The infection of plant roots with the bacteria Rhizobium and Bacterium tumefaciens results in the formation of polyploid cells (Wipf and Cooper 1940; Jakow ska 1949; D'A mato 1950).

In the present paper it has been established that the bacteria present in the external environment can act through secretions or through products of their autolysis on the cells of onion roots resulting in breakages of chromosomes, shortening of chromosomes, sticking together of chromosomes, aberrations in the division of chromosomes which can lead to the formation of polyploid nuclei and in general inhibition of the 
course of mitosis. It is not known what substances were responsible for the changes. Among the substances exuded by the bacteria or originating from the disintegration of bacterial cells the following may be noted: antibiotics, growth substances, amino acids, amines, amides, urea, nucleic acids and their precursors. These substances are known to be capable of inducing chromosomal aberrations and disturbances in cell divisions (A hnström and Natarajan 1966; Dubinin 1958, 1963, 1966).

The observed phenomenon, of the effect of substances of bacterial origin on the genetic apparatus of plant cells, appears to explain some ambiguous facts concerning spontaneous chromosome aberrations. To such facts one could include the observation that in some plants the rate of spontaneous chromosome aberrations is greater in the root meristems than in shoot meristems ( $\mathrm{N}$ avas hin and Ger a simova 1936, Gunihardt et al. quoted after Dubinin 1966; Cebrat in print). Difference in the level of chromosomal aberrations between root and shoot is possibly caused by the fact that roots are much more exposed to contact with becterial secretions than shoots. Also the fact that the level of chromosomal aberrations in roots of many plants seedlings increases with the age of the seeds ( $\mathrm{Nichols} 1941,1942$; Levan and Lofty 1950; Navashin 1933; Gustafsson 1937) may have been caused not only by the physiological changes taking place in ageing seeds, as the above mentioned authors suggest, but also by the increasing degree of infection by microorganisms. Also the apparently quite unusual observation that low levels of streptomycin can reduce the level of chromosomal aberrations in the roots of onion ( $\mathrm{D} u \mathrm{bin}$ in 1963) becomes readily explicable in the light of the present results. It seems most likely that the effect was achieved through the bacteriolytic action of the antibiotic.

\section{SUMMARY}

During introductory studies it was observed that the adventitious roots of Allium cepa $\mathrm{L}$. cultured in nonsterile conditions on tap water at room temperature differ in the level of chromosomal aberrations, the frequency of anaphases with bridges in relation to the anaphases with chromosome fragments, the length of chromosomes, the degree of synchronization of chromosome movements during anaphase and in the occurrence or non occurrence of dividing polyploid cells. A relation between these phenomena and the multiplication of bacteria in the water was noted. From the water two strains of bacteria were isolated which multiplied most - Agrobacterium and Flavobacterium. It was shown that the supernatant from these bacteria, following incubation in a Davis medium, causes chromosomes to become sticky, result in c-mitoses and in the formation of polyploid restitutional nuclei.

The authors wish to thank Prof. dr Z. Hejnowicz and Prof. dr H. Teleży ńs ki for numerous discussions and advices. 


\section{REFERENCES}

A hnström G. and A. T. N a t a r a j a n, 1966, Mechanisms of chromosome breakage. A new theory, Hereditas 54 (3): 379-388.

Cebrat J., 1971, Cytoembriologiczne badania nad przyczynami niskiej płodności uprawnych odmian lucerny mieszańcowej - Medicago media Pers., Postępy Nauk Rolniczych, w druku.

D'A mato F., 1950, Occasionale comparsa di radici altamente poliploidi in un bulbo di Cipolla, Caryologia 2: 160-164.

D u b in in N.P., 1958, Ob osnovnych faktorach estestvennego mutacionnogo procesa, Bot. Zurn. 43: 1093-1107.

D u b in in N.P., 1963, Molekuljarnaja genetika i dejstvie izlučenij na nasledstvennost, Gos.Atom.Izdat., Moskva.

D u b in in N.P., 1966, Èvoljucija populjacij i radiacija, Atom.Izdat., Moskva.

Gustafs on A., 1937, The different stability of chromosomes and the nature of mitosis, Heriditas 22: 281-335.

$\mathrm{Halkka}$ O., G. Meynadier, C. Vago and M. Brummer-Kornvenkotio, 1970, Rickettsial induction of chromosome aberrations, Hereditas 64 (1): 126-128.

$\mathrm{H}$ a m par B. and S.A. Ellison, 1961, Chromosomal aberrations induced by an animal virus, Nature 192 (4798): 145-146.

Hennen W.K., W.W. Nichols, A. Levan and E. Norrby, 1970, Polykaryocytosis and mitosis in a human cell line after treatment with measles virus, Hereditas 64: 53-84.

Jakowska S., 1949, Effects of Bacterium tumefaciens on Allium cepa, Phytopathol. 39:683-705.

Lederberg J., 1950, Isolation and characterisation of biochemical mutants of bacteria, Med.Res. 3: 5-22.

Levan A. and T. Lofty, 1950, Spontaneous chromosome fragmentation in seedlings of Vicia faba, Hereditas 36: 470-482.

Navaschin M., 1933, Altern der Samen als Ursachen von Chromosomenmutationen, Planta 20: 233-243.

$\mathrm{Navaschin} \mathrm{M.} \mathrm{and} \mathrm{H.} \mathrm{Geras} \mathrm{s} \mathrm{imova,} \mathrm{1936,} \mathrm{Nature} \mathrm{und} \mathrm{Ursachen} \mathrm{der} \mathrm{Muta-}$ tionen. Das Verhalten und die Zytologie der Pflanzen, die aus infolge Alterns mutierten Keimen stammen, Cytologia 7: 324-362.

Nichols C., 1941, Spontaneous chromosome aberrations in Allium, Genetics 26: $89-100$.

$\mathrm{Nichols} \mathrm{C.,} \mathrm{1942,} \mathrm{The} \mathrm{effects} \mathrm{of} \mathrm{age} \mathrm{and} \mathrm{irradiation} \mathrm{on} \mathrm{chromosomal} \mathrm{aberrations}$ in Allium seed, Amer.Jour.Bot. 29: 755-759.

Nichols W.W., 1963, Relationships of viruses, chromosomes and carcinogenesis, Hereditas 50: $53-80$.

Ni chols W.W., A. Levan, P. A u la and E. Norrby, 1964, Extreme chromosome breakage induced by measles virus in different in vitro systems. Preliminary communication, Hereditas 51: $380-382$.

Nichols W.W., A. Levan, P. A ula and E. Norrby, 1965, Chromosome damage associated with the measles virus in vitro, Hereditas 54: 101-118.

V a šk ova V.V. and D.K.L'vov, 1970, Vlijanie nekotorych arbovirusov na mitotičeskuju aktivnost i chromosomy kletok kultury tkani, Citol. i Genet. 4(4).: $300-303$.

Wipf L. and D.C. Cooper, 1940, Somatic doubling of chromosomes and nodular infection in certain Leguminosae, Amer.Jour.Bot. 27: 821-824.

Z a ts epin N.I., A.G. Stopchanskaya, G.I. Oleinik and N.L. Lys enko, 1970, Effect of adenoviruses and herpes simplex virus on human fibroblast chromosomes, Citol. i Genet. 4(4): 291-295. 


\section{Wstẹne badania nad wplywem bakterii na przebieg mitozy w korzeniach przybyszowych Allium cepa $\mathrm{L}$}

\section{Streszczenie}

We wstępnych obserwacjach stwierdzono, że korzenie przybyszowe cebul Allium cepa L. hodowanych w warunkach niesterylnych na wodzie wodociągowej, w temperaturze pokojowej, różnią się: poziomem aberracji chromosomowych, częstością występowania anafaz $\mathrm{z}$ mostkami chromosomowymi w stosunku do częstości występowania anafaz z fragmentami chromosowymi, długością chromosomów, stopniem synchronizacji ruchów chromosomów w anafazie, występowaniem, lub niewystępowaniem dzielących się poliploidalnych komórek. Zwrócono uwagę na zależność między tymi zjawiskami, a namnażającymi się w wodzie bokteriami. Z wody wyizolowano dwa szczepy bakterii, najliczniej w niej namnożone - Agrobacterium i Flovobacterium. Okazało się, że supernatant z tych bakterii hodowanych na płynnej pożywce Davisa powoduje sklejanie się chromosomów, c-mitozy i powstawanie poliploidalnych, restytucyjnych jąder. 